\title{
THE ACTION OF VARIOUS GOITROGENS IN INHIBITING LOCALIZATION OF RADIOIODINE IN THE THYROID AND THYMUS GLANDS OF LARVAL TREE TOADS
}

\author{
W. GARDNER LYNN ${ }^{1}$ AND JAMES NORMAN DENT ${ }^{2}$
}

Biology Division, Oak Ridge National Laboratory, ${ }^{3}$ Oak Ridge, Tenn., Department of Biology, The Catholic University of America, Washington 17, D. C., and Department of Biology, The University of Virginia, Charlottesville, Virginia

Because of the differential affinity of the thyroid gland for iodine, properly adjusted doses of radioactive iodine $\left(I^{131}\right)$ can produce enough radiation to destroy the thyroid completely without seriously damaging surrounding tissues. Immersion of tadpoles of Hyla versicolor at midlarval stages for 24 hours in a solution containing $20 \mu \mathrm{c} . / \mathrm{ml}$. of $\mathrm{I}^{131}$ results in rapid radiation damage to the thyroid so that no functional remnants are present after 10 days (Dent and Hunt, 1952). Administration of certain chemical substances known to inhibit the thyroid's ability to concentrate or bind iodine might be expected to prevent the thyroid from receiving enough radiation to cause permanent damage. Rugh (1953) found treatment with thiouracil effective in preventing or decreasing radiation damage in the thyroids of Triturus pyrrhogaster given a single injection of $\mathrm{I}^{131}(25 \mu \mathrm{c}$.).

Dent and Hunt (1952) observed that, in the tadpole, iodine is bound in other organs, notably the thymus, to a lesser degree than in the thyroid. It was demonstrated by Lynn and Dent (1957) that phenylthiourea inhibits iodine binding in both the thyroid and the thymus.

There are several different types of thyroid inhibitors with diverse modes of action. In the present study we have shown that some of them differ in degree and duration of effect by testing their capacities for preventing or diminishing radiation damage to the thyroid and thymus during administration of a large dose of $\mathrm{I}^{131}$.

\section{Materials and Methods}

Tadpoles of Hyla versicolor collected near Oak Ridge, Tennessee, were maintained in the laboratory at $21^{\circ} \pm 1^{\circ} \mathrm{C}$. until they reached late limb bud stages (equivalent to stages III to $\mathrm{V}$ of the Taylor and Kollros (1946) series). At this time they were divided into control and various experimental groups. Drugs to be tested were dissolved in the spring water in which the experimental animals were raised. The tadpoles were fed crumbled pellets of Purina Rat Chow, an excess of food being available for $\sim 8$ hours each day. The culture media were changed daily.

1 Present address: Department of Biology, The Catholic University of America, Washington $17, \mathrm{D}$. C.

2 Present address: Department of Biology, University of Virginia, Charlottesville, Va. Work supported in part by A. E. C. Contract AT-(40-1)-2000.

${ }^{3}$ Operated by Union Carbide Corporation for the U. S. Atomic Energy Commission. 

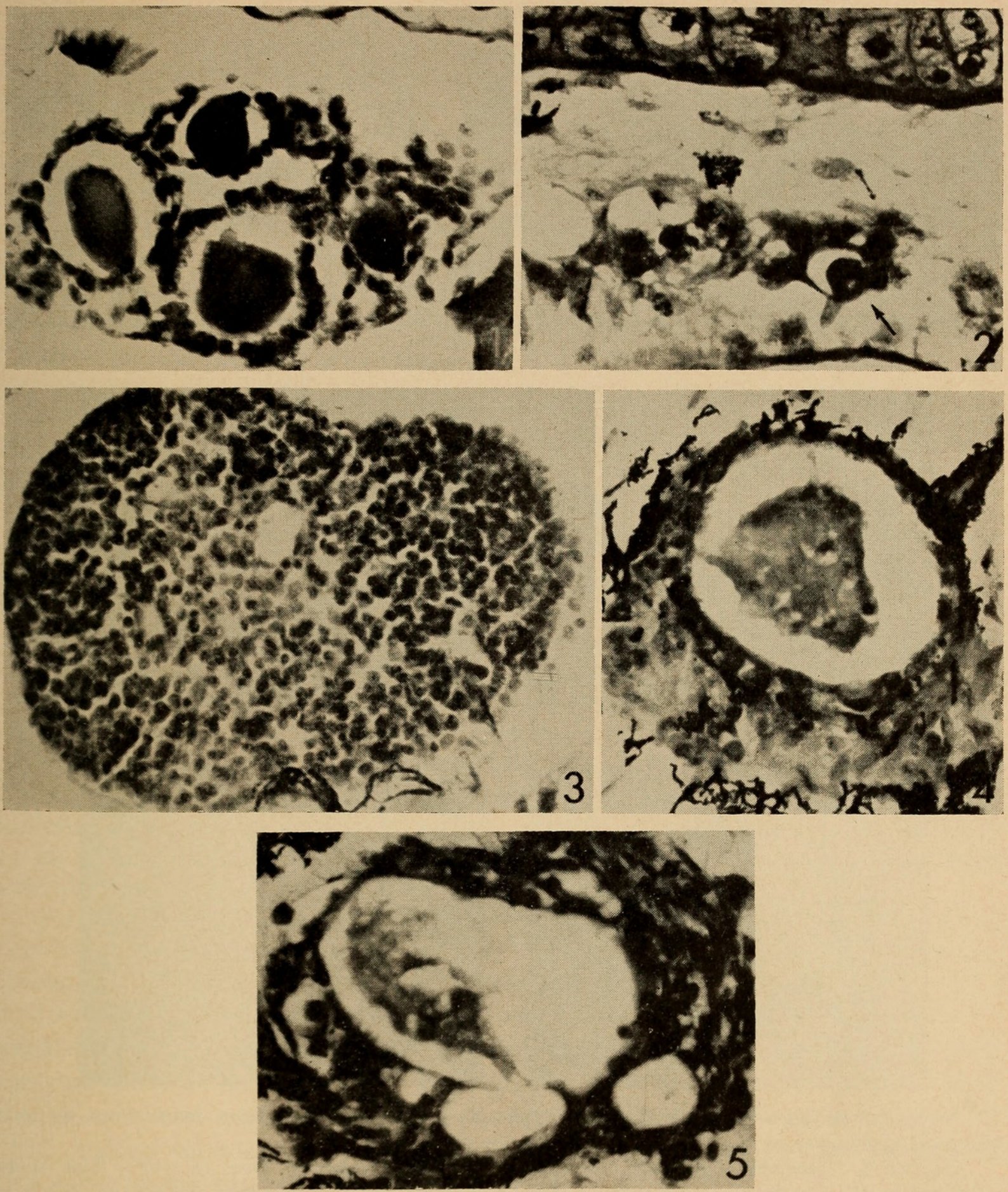

Figures 1 through 5 are photomicrographs of sections of larval specimens of Hyla versicolor.

Figure 1. Thyroid gland from control specimen with histological evidence of moderate secretory activity.

Figure 2. Arrow points to remnant of a thyroid follicle from an animal that received a thyroid-destroying dose of $\mathrm{I}^{131}$ and no goitrogen. Thyroid glands from most of the animals treated in this fashion were completely destroyed.

Figure 3. Thymus gland from control specimen. Note cords of cells and small sinus.

Figures 4 AND 5. Thymus glands showing severe radiation damage. The one in Figure 4 has a single cyst, the one in Figure 5 a large cyst and two smaller ones. 

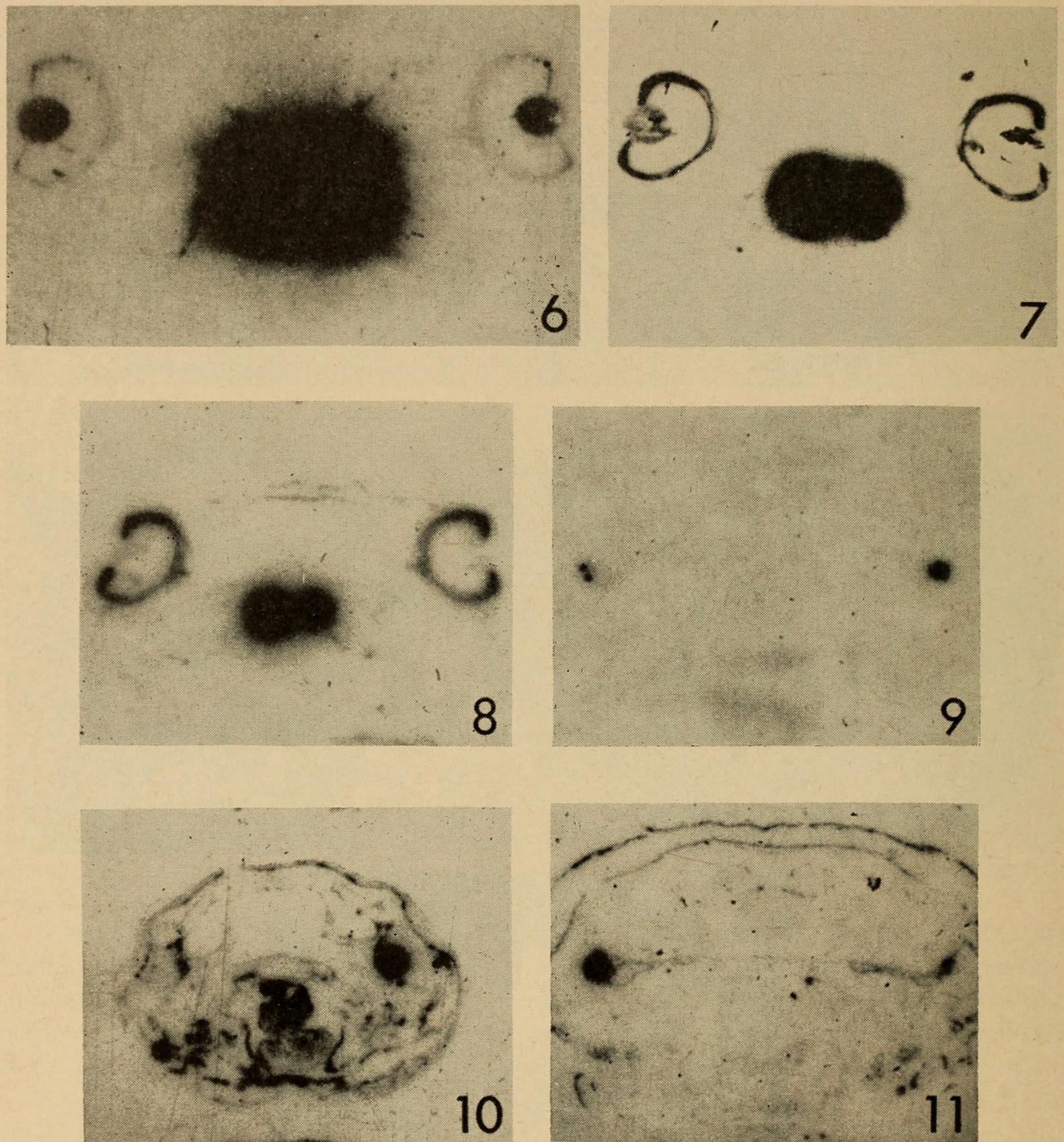

Figures 6 through 11 are photomicrographs of contact autoradiograms made from sections of larval specimens of Hyla versicolor treated with $\mathrm{I}^{131}$.

Figure 6. Thyroid region of control tadpole after a tracer dose of $I^{131}$. The spots produced by the two lobes of the thyroid gland are fused into a single spot the size of which is many times that of the gland (compare size of images of eyes).

FIGURE 7. Thyroid protected from the histological damage of the thyroid-destroying dose of $\mathrm{I}^{131}$ by goitrogen and then given a tracer dose of $\mathrm{I}^{131}$. The size of the spots indicates that the gland is functioning at a lesser rate than glands of control animals.

FIGURE 8. Thyroid protected from histological damage. No tracer dose was given. The iodine present is residual from the thyroid-destroying dose.

FiguRE 9. Thymus region of control animal given only a tracer dose of $\mathrm{I}^{131}$. The lobes of the thymus have produced the spots on either side of the photograph. They are slightly larger than the sections of the gland that produced them. The double spot on the left represents concentrations of $\mathrm{I}^{131}$ in two sinuses. The diffuse spot in the lower center represents the heart. 
After a 15-day period ${ }^{4}$ of goitrogen administration one series of tadpoles was given a large (thyroid-destroying) dose of radioiodine by immersion for 24 hours in a solution containing $20 \mu \mathrm{c}$. $/ \mathrm{ml}$. of $\mathrm{I}^{131}$. They were then passed through two baths of spring water and maintained in spring water, with the usual daily feeding schedule, for 10 days. These animals and some not previously exposed to radioiodine were given a tracer dose of radioiodine by immersion for 24 hours in a solution of $1 \mu \mathrm{c} . / \mathrm{ml}$. of $\mathrm{I}^{131}$. In a second series of animals, the same procedures were followed except that the tracer dose was omitted. All tadpoles were kept in spring water for an additional day and were then fixed in Bouin's fluid, embedded, and sectioned. Contact autoradiograms were prepared after the method of Dent and Hunt (1952) by apposing slides bearing sections of the larvae to Eastman medium-contrast lantern slide plates for an exposure time of 8 days. All sections were subsequently stained with Harris's hematoxylin and Ponceau de xylidine-orange II (Gray, 1952). Figures 1-5 are photomicrographs of sections of larval specimens. Figures 6-11 are photomicrographs of contact autoradiograms made from sections of larvae treated with $\mathrm{I}^{131}$.

\section{Results}

\section{Thyroid gland}

(a) Effects of radioiodine treatment on normal thyroid. Tadpoles kept continuously in spring water and given only the tracer dose of $\mathrm{I}^{131}$ provided the basic controls in this experiment. Histological observations of thyroid glands from eight such animals indicated moderate secretory activity (Fig. 1). Large follicles were lined with cuboidal epithelium and contained much acidophilic colloid. Chromophobe droplets were present at the periphery of the colloid mass in most follicles. The marked ability of these thyroids to concentrate iodine is evidenced by an intense black spot on the autoradiographic plates over each lobe that fused with the spot representing its companion lobe (Fig. 6).

Administration of the large dose of $\mathrm{I}^{131}$ to nine tadpoles resulted in complete destruction of the thyroid in six of them. In the other three, tiny spots running through two or three sections on the autoradiograms corresponded to minute thyroid remnants on the slides. Two of these remnants consisted of isolated colloid masses with no surrounding cells, the other of several follicles with severely damaged epithelia (Fig. 2). These tadpoles, having received no drugs, constitute the experimental controls of the series receiving the thyroid-destroying dose of $\mathrm{I}^{131}$. Table I summarizes the histological findings for all the experimental animals that received the large dose of $\mathrm{I}^{131}$.

${ }^{4}$ In preliminary experiments, the period of treatment with phenylthiourea varied from 25 to 9 days. Within these limits the protective effect was not correlated with the period of goitrogen administration. The standard period used in subsequent experiments was 15 days.

FIGURE 10. Thymus region of animal given both thyroid-destroying and tracer doses of $\mathrm{I}^{131}$. The large, dark spot on the right represents the right thymus; the left is not present in this section.

FIGURE 11. Thymus region of animal given only thyroid-destroying dose. Only a small part of the right thymus is present. The left thymus has produced a large spot, indicating considerable retention of $\mathrm{I}^{131}$. 
(b) Effects of treatment with phenylthiourea. In experiments performed to test the degree and duration of effect of phenylthiourea three variations in procedure were followed: (1) treatment with $0.01 \%$ phenylthiourea was continued during the 24 -hour period of $\mathrm{I}^{131}$ administration, the $\mathrm{I}^{131}$ solution being made up in phenylthiourea solution; (2) treatment with phenylthiourea was stopped at the time of $\mathrm{I}^{131}$ administration, the $\mathrm{I}^{131}$ solution being made up in spring water; (3) treatment was stopped two days before $\mathrm{I}^{131}$ administration.

The thyroids of eight tadpoles given phenylthiourea before and during $\mathrm{I}^{131}$ treatment were indistinguishable histologically from those of the basic control tadpoles, although their physiological activity was reduced in that they produced autoradiograms about half the size of those produced by control thyroids (Fig. 7).

When phenylthiourea treatment was discontinued at the time $\mathrm{I}^{131}$ administration was begun, the protective value of the treatment was greatly decreased. Thyroids of five animals handled in this manner showed extensive radiation damage with destruction of cells, pyknosis of nuclei, and, in some regions, complete disruption

TABLE I

Degree of radiation damage in thyroid glands of tadpoles after immersion in solutions of goitrogens and subsequent immersion in solutions containing $20 \mu \mathrm{c} . / \mathrm{ml}$. of $I^{131}$ (thyroids of controls immersed in iodine without goitrogen treatment were destroyed)

\begin{tabular}{|c|c|c|c|c|c|}
\hline \multirow{2}{*}{ Time of removal from goitrogen solution } & \multicolumn{5}{|c|}{ Drugs in which animals were immersed } \\
\hline & $\begin{array}{l}\text { Phenylthiourea } \\
(0.01 \%)\end{array}$ & $\begin{array}{c}\mathrm{KClO}_{4} \\
(0.01 \%)\end{array}$ & $\begin{array}{c}\mathrm{KSCN} \\
(0.005 \%)\end{array}$ & $\begin{array}{c}\mathrm{KClO}_{3} \\
(0.005 \%)\end{array}$ & $\begin{array}{c}\mathrm{KIO}_{3} \\
(0.005 \%)\end{array}$ \\
\hline $\begin{array}{l}\text { At end of } I^{131} \text { administration } \\
\text { At beginning of } I^{131} \text { administration } \\
\text { Two days before } I^{131} \text { administration }\end{array}$ & $\begin{array}{c}0 \\
++ \\
+++\end{array}$ & $\begin{array}{l}0 \\
0 \\
0\end{array}$ & $\begin{array}{c}0 \\
++ \\
+++\end{array}$ & $\begin{array}{l}0 \\
\text { NT } \\
\text { NT }\end{array}$ & $\begin{array}{l}0 \\
\text { NT } \\
\text { NT }\end{array}$ \\
\hline
\end{tabular}

Legend: $\quad 0=$ No histological evidence of radiation damage.

$++=$ Evidence of extensive radiation damage.

$+++=$ Evidence of complete or essentially complete destruction.

NT $=$ Not tested.

of follicles. Three of these thyroids produced no autoradiographic images; small isolated spots corresponding to less seriously damaged follicles were present in the others.

Discontinuance of phenylthiourea treatment two days before $I^{131}$ administration resulted in complete destruction of the thyroid.

(c) Effects of treatment with perchlorate. Three sets of experiments corresponding with those just described for phenylthiourea were carried out with $0.01 \% \mathrm{KClO}_{4}$.

In contrast with phenylthiourea, $\mathrm{KClO}_{4}$ completely protected the thyroid not only when given during $\mathrm{I}^{131}$ administration, but even when discontinued two days earlier. No histological abnormalities were seen in thyroid sections of this series, and autoradiograms showed dense spots representing the thyroids. Like those from thyroids protected by phenylthiourea, the spots were somewhat smaller than in untreated controls but indicated, nevertheless, a relatively high $\mathrm{I}^{131}$ content. 
Autoradiograms prepared from sections of animals that did not receive the tracer dose of radioiodine still showed small but definite spots for the thyroid (Fig. 8), indicating that a part of the heavy dose of radioiodine was retained in the protected glands.

Treatment with a lower concentration of $\mathrm{KClO}_{4}(0.005 \%)$ gave similar results, indicating that these two concentrations are equally effective.

(d) Effects of treatment with thiocyanate. Although animals were treated with both $0.01 \%$ and $0.005 \% \mathrm{KSCN}$, the higher concentration was so toxic that only a few animals survived the experiment, and they were discarded. The lower concentration prevented morphological damage to the thyroid when treatment was continued during $\mathrm{I}^{131}$ administration. Cessation of treatment at the time $\mathrm{I}^{131}$ was given, however, resulted in extensive damage, only a few badly disrupted remnants of the thyroid being discernible. These remnants were sometimes represented by tiny spots on the autoradiograms. Cessation of pretreatment two days before $\mathrm{I}^{131}$ administration resulted in complete destruction of the thyroid.

(e) Effects of treatment with chlorate and iodate. A single series of experiments was run to test the effects of treatment with $0.005 \% \mathrm{KClO}_{3}$ and $0.005 \%$ $\mathrm{KIO}_{3}$ that was continued during $\mathrm{I}^{131}$ administration. Under these conditions these substances prevented any visible histological damage to the thyroid. Autoradiograms showed large intense spots representing the glands.

\section{Thymus gland}

(a) Effects of radioiodine on the thymus of control animals. At the stage studied, the thymus gland is made up of loosely defined cords of cells surrounding small sinuses filled with lymphocytes and erythrocytes (Fig. 3) so that the gland presents a relatively compact appearance in section (Speidel, 1926; Dent and Hunt, 1952).

Administration of the large dose of $\mathrm{I}^{131}$ to previously untreated animals resulted in extensive damage to the thymus. In most of them the thymus was represented only by a single large vesicle with a few intact cells around the periphery (Fig. 4). Such glands produced much more intense spots on autoradiograms than did the normal thymus (Figs. 9 and 10). In the relatively few instances in which a number of separate vesicles were present (Fig. 5), rather than a single large one, the autoradiographic spots always corresponded to the vesicles. The material in these vesicles thus had a higher $\mathrm{I}^{131}$ content than the cells of the thymus.

(b) Effects of treatment with goitrogens. For all the preceding treatments discussed, histological and autoradiographic study was made of the thymus as well as the thyroid. Only one treatment proved completely effective in preventing thymus damage under the conditions of these experiments. Treatment with $0.01 \%$ $\mathrm{KClO}_{4}$ continued during $\mathrm{I}^{131}$ administration prevented cystic change in the thymus in all nine animals treated. Judging from the extent of damage, similar treatment with $0.005 \% \mathrm{KClO}_{4}$ or $0.005 \% \mathrm{KSCN}$ gave partial protection, but $0.005 \% \mathrm{KClO}_{3}$, $0.005 \% \mathrm{KIO}_{3}$ and $0.01 \%$ phenylthiourea gave none. No evidence of protection was seen in any tadpoles in which goitrogen treatment was discontinued before or at the time of $\mathrm{I}^{131}$ administration.

Any large vesicles present in the damaged thymus were represented by intense spots on autoradiograms. Because these spots were present whether or not a 
tracer dose of $\mathrm{I}^{131}$ was given (Figs. 10 and 11 ), it is evident that they resulted primarily from residual iodine of the original dose.

\section{Discussion}

Work with mammals indicates that, with the exception of phenylthiourea, the goitrogens used in this study interfere with the thyroid's function by inhibiting its ability to concentrate iodide (Wyngaarden et al., 1952). Phenylthiourea, however, permits iodide concentration but prevents its binding to protein (Pitt-Rivers, 1950; Roche and Michel, 1955). Under the experimental conditions of this investigation all these substances protected the thyroid against retaining sufficient $\mathrm{I}^{131}$ to cause histological damage to the gland, provided that the goitrogen treatment was continued during the administration of $\mathrm{I}^{131}$, whereas only $\mathrm{KClO}_{4}$ was effective when pretreatment was discontinued either two days before or immediately before $I^{131}$ administration.

Longer periods between the administration of the large $\mathrm{I}^{131}$ dose and fixation of the specimens might produce progressive damage since even those thyroids that were considered to have been completely protected retained a large amount of $I^{131}$ 10 days after the thyroid-destroying dose was given. In mice, damage resulting from a low dose $\left(25 \mu \mathrm{c}\right.$.) of $\mathrm{I}^{131}$ is not apparent until many months after the iodine has been injected (Dent, Gadsden and Furth, 1955). Our experiments, however, were directed toward testing the relative effectiveness and duration of effect of the various goitrogenic drugs and were not concerned with devising a method for protecting the thyroid from radiation damage. Continuation of the goitrogen treatment for some time after exposure to $\mathrm{I}^{131}$ would presumably provide complete protection.

It is also noteworthy that, in a number of the experiments in which the thyroid seemed completely undamaged histologically, autoradiograms nevertheless indicated that the gland's ability to take up ${ }^{131}$ from the tracer dose was considerably decreased. This may be interpreted as evidence of physiological damage in the absence of histological changes, or it may indicate a residual inhibitory effect of the drug as seen in the rat after the administration of propyl thiouracil (Durbin et al., 1957).

The only similar experiments with an amphibian are those of Rugh (1953), in which adult specimens of Triturus pyrrhogaster were given a series of four intraperitoneal injections of a $1 \%$ suspension of thiouracil over a period of 3 weeks. These animals and untreated controls then received an intraperitoneal injection of $25 \mu$ c. of $I^{131}$. The first indications of damage to the thyroid were seen in the controls after one month, and almost complete destruction had occurred by two months. The specimens given thiouracil showed no damage at one month, minor damage at two months, and clear signs of protection even at 7 months. Even more complete protection might have been afforded, Rugh pointed out, by continuing administration of the goitrogen after $\mathrm{I}^{131}$ treatment. Although our experiments were undertaken with a different aim and technique, our results are in accord with those of Rugh.

Our observations also confirm the earlier observation of Dent and Hunt (1952) that the amphibian thymus has a differential affinity for $\mathrm{I}^{131}$ and that cystic changes 
occur in this gland when sufficient $I^{131}$ is administered. The amount of $I^{131}$ taken up by the thymus is apparently quite low compared with that concentrated by the thyroid. $I^{131}$ concentration in cysts of damaged thymus tissue is apparently much higher than in normal cells of the thymus.

The protective action of goitrogenic drugs in the thymus differed from that in the thyroid. Only one treatment $\left(0.01 \% \mathrm{KClO}_{4}\right.$ continued during $\mathrm{I}^{131}$ administration) completely prevented cystic changes in the thymus. None of the drugs provided any protection for the thymus if their use was discontinued before $\mathrm{I}^{131}$ administration. These goitrogens are all believed to interfere with the thyroid's ability to take up iodine from the circulating blood. Since $\mathrm{KClO}_{4}$ was the most effective inhibitor of $\mathrm{I}^{131}$ uptake by both thyroid and thymus, the same mechanism may be operative in both cases. The lesser degree of effectiveness of the drugs for the thymus compared with the thyroid may indicate that the thymus is damaged by lower radiation levels than is the thyroid.

Although protective to the thyroid, phenylthiourea proved to be completely without protective value in the thymus. Although phenylthiourea caused a decrease in $I^{131}$ uptake by the thymus (Lynn and Dent, 1957), the present results indicated that this reduction is not sufficient to protect the thymus from damage by a thyroid-destroying dose of $\mathrm{I}^{131}$.

\section{SUMMARY}

1. Larvae of Hyla versicolor were immersed for 15 days in spring water containing phenylthiourea, $\mathrm{KClO}_{4}, \mathrm{KSCN}, \mathrm{KClO}_{3}$, or $\mathrm{KIO}_{3}$ followed by a 24-hour immersion in $20 \mu \mathrm{c}$. $/ \mathrm{ml}$. of $\mathrm{I}^{131}$, a thyroid-destroying dose.

2. When treatment with any one of these drugs was continued during the period of $\mathrm{I}^{131}$ administration, radiation damage to the thyroid was prevented.

3. The inhibitory effect of $\mathrm{KClO}_{4}$ on the thyroid persisted even when treatment was discontinued two days before immersion in the $\mathrm{I}^{131}$ solution.

4. The effects of phenylthiourea and $\mathrm{KSCN}$ were dissipated more quickly since the thyroid showed extensive damage when treatment was stopped immediately before $\mathrm{I}^{131}$ administration and complete destruction when it was stopped two days before.

5. In control animals, the thyroid-destroying dose of $\mathrm{I}^{131}$ extensively damaged the thymus gland as well.

6. Of the drugs tested, only $\mathrm{KClO}_{4}$ sufficiently inhibited the $\mathrm{I}^{131}$ uptake by the thymus to prevent damage, and only when it was present during the period of exposure to $\mathrm{I}^{131}$.

\section{LITERATURE CITED}

Dent, J. N., And E. L. Hunt, 1952. An autoradiographic study of iodine distribution in larvae and metamorphosing specimens of anura. J. Exp. Zool., 121: 79-98.

Dent, J. N., E. L. Gadsden and J. Furth, 1955. On the relation between thyroid depression and pituitary tumor induction in mice. Cancer Res., 15: 70-75.

Durbin, P. W., C. W. Asling, M. E. Johnston and J. G. Hamilton, 1957. The effect of propyl thiouracil on the recovery of rat thyroid gland from irradiation with astatine 211. Anat. Rec., 129: 17-37.

Gray, P., 1952. Handbook of Basic Microtechnique. Blakiston Company, Philadelphia.

Lynn, W. G., And J. N. Dent, 1957. Phenylthiourea treatment and binding of radioactive iodine in the tadpole. Biol. Bull., 113: 160-169. 
Pitt-Rivers, R., 1950. Mode of action of antithyroid compounds. Physiol. Rev., 30: 194-205. Roche, J., ANd R. Michel, 1955. Nature, biosynthesis and metabolism of thyroid hormones. Physiol. Rev., 35: 583-610.

Rugh, R., 1953. Thiouracil modification of effect of radioiodine (I131) on the thyroid. Radiology, 61: 391-400.

Speidel, C. C., 1926. Studies of hyperthyroidism. II. The significance of changes in the thymus glands of thyroid-treated frog tadpoles. Amer. J. Anat., 37: 141-157.

Taylor, A. C., and J. J. Kollros, 1946. Stages in the normal development of Rana pipiens larvae. Anat. Rec., 94: 7-23.

Wyngaarden, J. B., B. M. Wright and P. Ways, 1952. The effect of certain anions upon the accumulation and retention of iodide by the thyroid gland. Endocrinology, 50: $537-539$. 


\section{$2 \mathrm{BHL}$ Biodiversity Heritage Library}

Lynn, W Gardner and Dent, James Norman. 1960. "The action of various goitrogens in inhibiting localization of radioiodine in the thyroid and thymus glands of larval tree toads." The Biological bulletin 118, 430-438. https://doi.org/10.2307/1538821.

View This Item Online: https://www.biodiversitylibrary.org/item/110976

DOI: https://doi.org/10.2307/1538821

Permalink: https://www.biodiversitylibrary.org/partpdf/2146

\section{Holding Institution}

Smithsonian Libraries

\section{Sponsored by}

Biodiversity Heritage Library

\section{Copyright \& Reuse}

Copyright Status: In copyright. Digitized with the permission of the rights holder.

License: http://creativecommons.org/licenses/by-nc-sa/3.0/

Rights: https://biodiversitylibrary.org/permissions

This document was created from content at the Biodiversity Heritage Library, the world's largest open access digital library for biodiversity literature and archives. Visit BHL at https://www.biodiversitylibrary.org. 